\title{
De Estacão de Cura à Balneabilidade Duvidosa: Análise Ambiental das Praias do Bairro Rio Vermelho, Salvador, Bahia
}

\section{Station Healing to Doubtful Bathing: Environmental Analysis from the Neigh- borhood Rio Vermelho's Beaches, Salvador, Bahia}

Kallenya Thays Lima Limeira Oliveira *

\begin{abstract}
Resumo:
A partir de um bairro baiano de importância histórica, o bairro Rio Vermelho, buscou-se evidenciar como ações antrópicas podem afetar negativamente o meio ambiente. Ressalta-se o expressivo contraste temporal nas praias que há um século vivenciavam período de intenso veraneio, consistindo no primeiro balneário turístico da Bahia, mas, na atualidade, são predominantemente impróprias ao banho. A fim de compreender a realidade destas praias, além de pesquisa bibliográfica e acompanhamento das condições de balneabilidade, foram entrevistados moradores e pescadores e procedeu-se à análise ambiental das praias, conforme NBR ISO 14004, a qual caracteriza com maior precisão a situação ambiental das mesmas, contribuindo para uma avaliação mais robusta para, oportunamente, servir de respaldo a políticas públicas.
\end{abstract}

* Secretaria Municipal de Meio Ambiente de Aparecida de Goiânia. Mestra em Economa pela UFBA

\section{Abstract:}

From a historically significant neighborhood for Salvador sought to show how human actions can negatively affect the environment. It should be noted the significant temporal contrast in the beaches that a century ago were experiencing intense summer period, consisting of the first tourist resort of Bahia, but, at present, are predominantly unfit for bathing. In order to understand the reality of these beaches, as well as bibliographic research and monitoring of bathing conditions, was interviewed residents and fishermen and proceeded to the Initial Environmental Analysis of beaches, according to NBR ISO 14004, which characterizes more precisely the environmental situation the same, contributing to a more robust assessment to, in due course, serve as a support to public policies.
Palavras-chave:

Análise Ambiental Inicial

(AAI),

NBR ISO 14004

Bairro Rio Vermelho,

Percepção ambiental

Key-Words:

Initial Environmental Analysis,

NBR ISO 14004,

Rio Vermelho district, Environmental perception 


\section{INTRODUÇÃO}

Desde a pré-história a existência humana causa impactos ao meio ambiente, de forma crescente e consoante à expansão da atividade econômica. À medida que passou a conhecer e dominar mais o ambiente em que vive o homem desenvolveu processos que induziram à degradação ambiental. Os impactos ambientais de origem antrópica decorrem de atividades de produção e consumo e geralmente estão relacionados à ocupação do espaço físico, à extração de recursos naturais como fator de produção e às descargas residuais poluentes (MATA, 2001, p.1). De acordo com Martins (2011, p.91) "é esperado que ocorram perdas significativas na biodiversidade marinha diante processos de urbanização não planejados e episódios de contaminação antrópica", além disso, tais fatores também geram impactos ambientais negativos sobre as cidades e, especificamente, sobre o uso recreativo das praias. Logo, a passagem das praias do bairro Rio Vermelho de estação de cura para balneabilidade duvidosa, objeto deste artigo, está associada ao processo de urbanização do bairro.

A Cidade de Salvador é uma das capitais brasileiras com fortes atrativos turísticos e culturais, devido a seus atributos históricos e naturais. Estes atributos são claramente identificados no bairro Rio Vermelho, importante local de referência turística da cidade. Porém, a beleza natural que atribuiu às praias do bairro o título de primeiro balneário turístico da Bahia, conforme Porto Filho (2009, p.45), já não detém os mesmos encantos ambientais, devido à drástica alteração em sua geografia, em decorrência da construção do emissário submarino inaugurado em 1975 e, sobretudo, pelo processo de poluição oriunda do rio Lucaia que deságua na praia da Mariquita, intensificado nos últimos 40 anos (PORTO FILHO, 2009, p.45).

Durante a realização da pesquisa de campo, considerou-se uma praia limpa, como aquela em que, além da água ser diagnosticada como própria para o banho, não tenha aparente poluição da água ou disposição de resíduos sólidos nas areias intimidando as atividades de recreação e banho. Essa definição visa respaldar a caracterização do mínimo desejável para uma praia limpa, tendo em vista as inconformidades encontradas na paisagem das praias do bairro.

Com topografia bastante acidentada, atualmente a orla do bairro Rio Vermelho comporta as praias Sereia, Paciência, Santana, Mariquita e Buracão, entretanto, somente esta última apresenta condições de limpeza satisfatória. Há pontos nas demais praias em que a poluição é evidente pela presença de efluentes e resíduos sólidos diversos, tornando-as repulsivas, principalmente as praias de Santana e da Mariquita. A partir das entrevistas realizadas pela autora aos moradores e pescadores, verifica-se que as praias do bairro Rio Vermelho, com exceção da praia do Buracão, e por ventura da praia da Paciência, não são consideradas limpas.

Embora algumas praias do bairro apresentem concentração de resíduos sólidos e odor, por várias vezes são atestadas pelo Instituto Estadual de Meio Ambiente (INEMA) como adequadas ao banho. Os pontos de monitoramento da qualidade da água das praias do Rio Vermelho localizam-se nas praias de Santana e da Paciência e seu diagnóstico observa o artigo $2^{\circ}$ da resolução $n^{\circ} 274 / 00$ do Conselho Nacional de Meio Ambiente (CONAMA), segundo o qual, a balneabilidade é satisfatória quando (...)

(...) em $80 \%$ ou mais de um conjunto de amostras obtidas em cada uma das cinco semanas anteriores, colhidas no mesmo local, houver, no máximo 1.000 coliformes fecais (termotolerantes) ou 800 Escherichia coli ou 100 enterococos por 100 mililitros. (BRASIL, 2000).

Entretanto, esta condição para balneabilidade não assegura a limpeza das praias. Como exposto, os pontos de coleta no bairro Rio Vermelho são restritos a duas praias ${ }^{1}$, excluindo do monitoramento a praia da Mariquita, onde se encontra a Foz do Rio Lucaia, sendo, portanto, a mais exposta à poluição. Ademais, seria um contrassenso considerar limpas praias com balneabilidade satisfatória e constante presença de resíduos, conforme podem ser observados nas praias diariamente. Consequentemente, a caracterização dessas praias exige uma análise mais ampla; portanto, optou-se por aplicar a Avaliação Ambiental Inicial (AAI) conforme estabelecida pela NBR ISO 14004 (ASSOCIAÇÃO BRASILEIRA DE NORMAS TÉCNICAS, 2007).

Apesar de as praias do Rio Vermelho não consistirem em uma empresa, corporação ou instituição com funções e administração próprias, não caracterizando, portanto, uma organização, decidiu-se pela AAI, conforme a NBR ISO 14004, em função de sua aplicabilidade e abrangência para auxiliar em sua caracterização.

\section{METODOLOGIA}

A NBR ISO 14004 é uma série de normas desenvolvidas pela Internacional Organization for Standardi- 
zation (ISO) que estabelecem instruções normativas para o estabelecimento, implementação e manutenção de um Sistema de Gestão Ambiental (SGA) e inclui termos, definições, diretrizes e recomendações. Dentre as recomendações às organizações que se dispõem a aplicá-las está o estabelecimento da Avaliação Ambiental Inicial (AAI), que visa proporcionar uma auto-avaliação da posição atual em relação ao meio ambiente, sendo, portanto, introdutória e indispensável para o estabelecimento do SGA. No caso de já haver um SGA, a AAI ainda poderá ser útil no seu aprimoramento.

Adotou-se a recomendação de incluir quatro dimensões-chave da AAI - identificação de aspectos ambientais $^{2}$; identificação de requisitos legais aplicáveis; exame das práticas e procedimentos ambientais existentes; $\mathrm{e}$ avaliação de situações emergenciais e acidentes anteriores. Adicionalmente, com a finalidade de compreender melhor o bairro onde estas praias estão inseridas, buscou-se informações a respeito de sua socioeconomia e história.

Para atender às recomendações da AAI e aos objetivos propostos, fez-se uso de dados estatísticos divulgados pelo Instituto Brasileiro de Geografia e Estatística (IBGE), de pesquisa bibliográfica relativa à bacia hidrográfica do rio Lucaia e ao bairro Rio Vermelho, de listas de verificação (checklist) e de informações dos moradores e pescadores sobre o estado ambiental local, obtidas a partir de entrevistas estruturadas com 270 moradores e 31 pescadores, realizadas exclusivamente pela autora, com perguntas abertas e fechadas.

Foram realizados dois check-lists para cada praia, o primeiro em dia comercial e o segundo em final de semana, observando-se o tempo - ensolarado, nublado ou chuvoso. Foram identificadas as condições inadequadas nos seguintes ítens: acesso à praia (calçada, escada, outro); areia (limpeza do ambiente, lixeiras, banheiros, erosões, ruídos, serviços de apoio - lanchonete, outras situações); água (sinalização de balneabilidade, aparência visual da água, sólidos flutuantes, algas, canais de efluentes, odor, outros); animais (cachorros, gatos, ratos, pombos, baratinhas da praia, moscas, outros); segurança (salva-vidas, sinalização de perigo, outras situações). Também foi realizada a caracterização natural das praias, identificadas as atividades desenvolvidas no momento da vistoria e listagem dos resíduos sólidos encontrados.

Para garantir a organização e fluência do questionário, perguntas afins foram dispostas juntas compondo quatro blocos temáticos separados por cabeçalhos: o primeiro bloco tinha por função a triagem, pois consiste em verificar se o entrevistado reside no bairro, condição necessária para entrevista, e em registrar o logradouro de sua residência; o segundo bloco mesclou questões sobre a avaliação do entrevistado a respeito do bairro, serviço de esgotamento e responsabilidade ambiental, sendo intitulado como 'Apresentação do tema'. Este bloco ofereceu suporte para avaliar a percepção ${ }^{3}$ e a consciência ambiental do entrevistado, que são elementos evidenciados caso cite o problema de esgotamento do bairro, quando chamado para avaliar este aspecto, e se compartilha da responsabilidade pela preservação da praia limpa. O terceiro bloco intitulou-se de 'Perfil' e compôs-se de questões pessoais sobre a caracterização socioeconômica. $\mathrm{O}$ quarto e último bloco foram sobre perguntas de valoração ambiental e recebeu o título de 'Sua opinião'.

No intuito de garantir aleatoriedade, a amostra de 270 moradores foi dividida em subamostras, respeitadas as proporções de moradores em cada setor censitário definido pelo IBGE (IBGE, 2010).

\subsection{O objeto de estudo em seu contexto: o bairro Rio Vermelho}

Localizado no litoral norte de Salvador, com três quilômetros de orla marítima, entre os bairros Ondina e Amaralina, o bairro Rio Vermelho situa-se a $25 \mathrm{~km}$ de distância do Aeroporto Internacional Deputado Luis Eduardo Magalhães e a $9 \mathrm{~km}$ do centro-histórico da cidade. Tomando-se como referência a igrejinha do largo de Santana, encontra-se nos arredores das seguintes coordenadas geográficas: $13^{\circ} 00^{\prime} 41.15^{\prime \prime}$ S e $38^{\circ} 29^{\prime} 30.99^{\prime \prime} \mathrm{W}$ (PORTO FILHO, 2009, p.13).

O bairro integra a bacia hidrográfica do rio Lucaia, o qual segue alimentado por redes de drenagem pluviais e consequente carreamento adicional de resíduos. Neste bairro, mais precisamente no Largo da Mariquita, encontra-se a foz do rio Lucaia, último afluente natural da primitiva foz do rio Camarogipe ${ }^{4}$, a qual foi desviada, na década de 1970, para a região situada hoje entre a Praça Jardim dos Namorados e a Praia de Jardim de Alah, ambas no bairro Costa Azul, em razão das constantes enchentes que ocorriam nas zonas mais baixas do bairro Rio Vermelho (SANTOS et al., 2010, p. 81).

Tendo em vista que o rio que dá nome ao bairro já não o percorre, como era seu trajeto natural, o que restou 
foi a drenagem de efluentes transformando em canal o trecho final do rio Lucaia que, por sua vez, deságua na praia da Mariquita carreando efluentes e resíduos sólidos facilmente perceptíveis pelos passantes.

\subsection{Perfil socioeconômico}

Devido à ausência de uma legislação que delimite os bairros de Salvador, não há uma delimitação oficial para o bairro Rio Vermelho; contudo, conforme contagem do censo demográfico de 2010, baseado na delimitação realizada em trabalho recente pela Universidade Federal da Bahia (UFBA) em parceria com diversos órgãos do estado e município (SANTOS et al., 2010) ${ }^{5}$, a população do referido bairro é de 18.334 habitantes, revelando crescimento de 3,79\% em relação ao Censo anterior (2000).

Alguns aspectos levantados pelo Censo demográfico de 2010 ajudam a traçar o perfil populacional deste bairro: moderado índice de envelhecimento $(81,14)$; baixa concentração de negros (54,85\% de pessoas de cor ou raça negra), tendo em vista o padrão da cidade o qual é de $79,45 \%$ da população formada por pessoas de cor ou raça negra. Trata-se de uma população com baixo índice de analfabetismo $(0,95)$,na qual menos de $1 \%$ dos moradores vivem em situação de extrema pobreza.

\subsection{Histórico}

A história do Rio Vermelho inicia-se 40 anos anteriores à fundação da cidade de São Salvador da Bahia de Todos os Santos. Sua origem é marcada pelo início de 1509, com o naufrágio da embarcação em que tripulava Diogo Álvares Corrêa, junto ao Morro do Conselho. Este jovem de nacionalidade discutível foi estratégico em sua aparição aos nativos, o que lhe rendeu o respeito e a confiança dos mesmos. Segundo versão mais aceita entre os historiadores, quando foi avistado pelos índios, atirou certeiramente em uma gaivota em pleno voo, então os índios espantados exclamaram " $\mathrm{Ca}$ ramuru! Caramuru! Caramuru!" que na língua tupi significa 'homem do fogo, filho do trovão, dragão saindo do mar' e passou a ser o apelido do náufrago. Caramuru possibilitou a comercialização do pau-brasil com franceses, o que não garantiu a fixação de estrangeiros (PORTO FILHO, 2009, p.15-19).

No século XVII o Rio Vermelho era uma colônia de pescadores, tornando-se mais povoado ao abrigar parte da população de Salvador que fugia da invasão dos holandeses de 1624. No século XIX três núcleos de povoamento se apresentavam consolidados: Paciência, Mariquita e Santana. Contudo, a expansão do bairro só se deu no século XX, no governo de J. J. Seabra (SANTOS et al., 2010, p.78).

$\mathrm{Na}$ década de 1950 ganhou fama de bairro dos artistas' devido à concentração de artistas plásticos, músicos, cantores, compositores, atores, escritores e poetas residentes (PORTO FILHO, 2009, p.32). O Rio Vermelho atual caracteriza-se como zona de concentração comercial e de serviços, também conhecido por sua boemia, desde o período em que se constituía num glamoroso centro de veraneio, e é tido como o bairro de Salvador que nunca dorme.

O bairro é marcado pela popular Festa de Iemanjá, a maior e mais importante homenagem dentre as prestadas à Iemanjá em diversos países, segundo Small (1980, apud PORTO FILHO, 2009, p. 60) e pelos tabuleiros de acarajé, dentre eles, o mais famoso do país, o de Dinha, quituteira que em muito contribuiu para valorização de sua classe e que hoje é comandado por sua filha Cláudia.

\subsection{As praias do Rio Vermelho: de estação de cura à balneabilidade duvidosa}

No século XIX as praias do Rio Vermelho atraiam pelas 'águas milagrosas de seu mar' que, segundo crenças da época, curavam até beribéri. Em consequência disto, os banhos de sal em suas "águas medicinais" atraiam pessoas de diversas procedências (PORTO FILHO, 2009, p. 23). Logo o local tornou-se o recanto preferencial do veraneio das familias ricas. Constituiu-se no primeiro balneário turístico da Bahia, tendo seu ápice no período de 1880 a 1930, quando motivou a construção de casarões, clubes, hotéis com restaurantes e diversificou o comércio (PORTO FILHO, 2009, p. 23).

Com o desenvolvimento e crescimento da população fixa, o bairro foi perdendo o atrativo como reduto de veraneio (PORTO FILHO, 2011). Desde a época de intenso veraneio (1880-1930) até a fixação de maior população, todas as nove praias do Rio Vermelho - sentido sul-norte: Sereia, Avenida, Paciência, Santana, Forte, Mariquita ${ }^{6}$, Fonte do Boi, Nita Costa e Buracão - eram bastante frequentadas. Porém, Porto Filho (1991, p. 31-32) narra uma série de transformações ocorridas no bairro nas décadas de 60 e 70 que, direta ou indiretamente, transformaram a paisagem das praias.

Segundo Porto Filho (1991, p. 31) o Rio Vermelho permanecia como reduto tranquilo, preservando grande parte de suas tradições e características próprias até os anos 60 . Contudo, na década de 70, diversas transformações colabo- 
raram intensamente para a degradação ambiental do bairro e de suas praias. Associadas ao intenso crescimento populacional têm-se, por exemplo, a destruição de fontes de água e a ocupação de áreas verdes e, ocasionando grandes modificações nas praias, a construção do emissário submarino iniciada em 1972.

Dessa forma, marcaram a década, ao mesmo tempo em que mudavam o perfil do bairro, a construção de duas grandes avenidas de vale, a Juracy Magalhães Júnior e a Anita Garibaldi; a implantação do parque Primavera e vários outros núcleos residenciais; e o início da ocupação dos morros do Conselho e do Menino Jesus, como reflexo do boom imobiliário verificado praticamente em toda Salvador; concomitantemente à destruição de dezenas de casas e casarões de antigos moradores que migraram motivados pela especulação imobiliária (PORTO FILHO, 1991, p. 32, cap. 1,). Assim, o Rio Vermelho perdeu seu aspecto provincial e sua imagem de bairro pacato foi substituída pelo intenso tráfego de veículos e tumulto da vida moderna (PORTO FILHO, 1991, p. 261, cap. 17).

Porto Filho (2009, p. 47) narra a significativa transformação ocorrida na paisagem das praias após a construção do emissário submarino. Segundo o autor, um aterro de 20 mil metros quadrados engoliu a enseada da Mariquita e desencadeou o desaparecimento das praias do Forte e da Paciência, a praia de Santana teve seu volume de areia reduzido e as praias da Avenida (atual Paciência), Buracão e Nita Costa tiveram um substancial acréscimo, no caso das duas últimas o grande volume de areia submergiu os rochedos que as separavam. $\mathrm{O}$ historiador também traça, em entrevista, um painel sobre a poluição das praias:

(...) Com o emissário, os prédios novos que surgiam começaram a canalizar seus esgotos para a rede pluvial. Então as praias passaram a ficar poluídas. Inclusive o CRA, logo que surgiu, passou a fazer uma medição semanal do grau de poluição das praias. Começava no distrito ferroviário e ia até a praia do Flamengo. Semanalmente publicava nos jornais: 'praias recomendáveis para banhos e praias não recomendáveis'. As praias do Rio Vermelho, TODAS, passaram a ser não recomendáveis para banhos. E botaram placas 'Praia não recomendável'. Em função de em toda semana, o nível de medição ser aquele mesmo de poluição, ou seja, poluição já permanente, aí o CRA colocava placas. [...] E como se não bastasse a $\mathrm{EMBASA}^{7}$ dá umas descargas, periodicamente. Às vezes você passa o leito tá vazio, a água do mar sobe, agora tem vez que chega lá e tem aquela água escura assim dessa cor [apontando para a mesa de madeira marrom escuro] empoçada. Às vezes desce até aquela correnteza, dejectos da Embasa, e isso tudo vai para o mar. Então, os dois rios estão mortos [Rio Lucaia e Rio Vermelho]. E viraram canais de dejectos a céu aberto. E tudo isso vai pra praia. (PORTO FILHO, 2011).

De acordo com Porto Filho (2011), a implantação do emissário coincidiu com a perda da maioria de seus casarões e palacetes, e o fenômeno da poluição das praias do bairro tem relação direta com a edificação dos prédios novos após a construção do emissário submarino, que se tornou, portanto, um marco para o perfil arquitetônico do bairro e para as praias. O Quadro 1 localiza as praias existentes no bairro originalmente e após a implantação do emissário submarino.

No Rio Vermelho é impossível caminhar ininterruptamente pela beira do mar, que liga Ondina a Amaralina. Isto ocorre em função da topografia acidentada com a existência de cordões rochosos e de três morros: da Sereia, do Conselho e do Menino Jesus. As faixas arenosas das praias receberam denominações particulares, pela ordem exposta no Quadro 1, no sentido sul-norte (PORTO FILHO, 2009, p. 45).

Quadro 1 - Praias do Rio Vermelho.

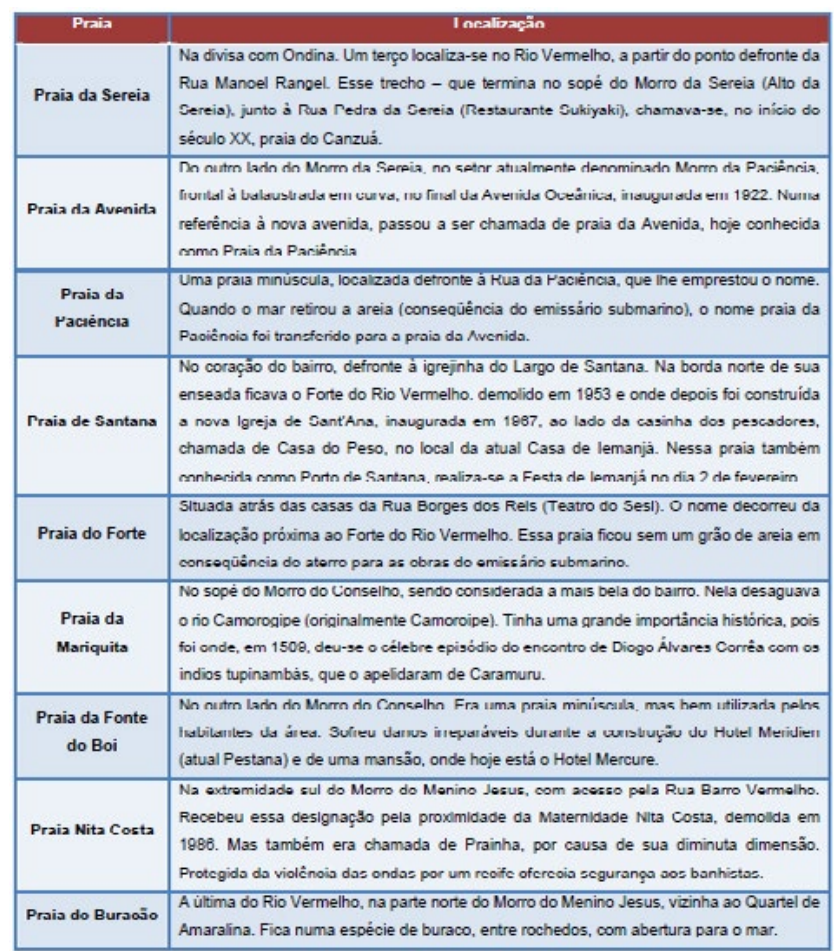

Fonte: Elaboração própria, 2012 com base em PORTO FILHO, 2009, p. 46-47.

Atualmente o Rio Vermelho dispõe, no sentido sul norte, das seguintes praias: Sereia, Paciência, Santana, Mariquita e Buracão. O nome Buracão é atualmente utilizado também para designar a antiga Praia Nita Costa (também conhecida como Prainha), posto que após o advento do emissário submarino uma grande quantidade de areia foi depositada pelo mar ocasionando a junção das duas praias. Segundo depoimento de Porto Filho (2011) à autora, a praia da Mariquita que havia perdido sua areia com o surgimento do emissário está sendo reconstituída, pois há cerca de 3 anos 
o mar deposita areia; contudo, é com certeza a mais poluída pois fica na 'boca do rio', deste modo, considerando-se o fator localização, as menos poluídas são Buracão e Paciência.

$\mathrm{O}$ rápido crescimento populacional retratado anteriormente, sob evidências de ter ocorrido sem estrutura de saneamento adequada e com ausência de fiscalização preventiva, ajuda a compreender a poluição das praias, pois o direcionamento dos efluentes para as praias e as ligações clandestinas não poderiam resultar em um cenário diferente. A existência de ligações clandestinas no bairro Rio Vermelho foi atestada durante pesquisa de campo e também é evidenciada para a bacia do Rio Lucaia de tal modo que todos os pontos de monitoramento da qualidade de suas águas registraram forte odor característico do lançamento de esgotos (SANTOS et al., 2010, p. 45). A existência de ligações clandestinas de efluentes à rede pluvial, na Bacia Hidrográfica do Rio Lucaia relaciona-se a (...)

(...) dificuldades topográficas, resistência por parte de cidadãos em conectar seus imóveis à rede pública coletora de esgotamento sanitário, ocupação desordenada, com a existência de imóveis sobre galerias e canais de drenagem, em fundos de vale e encostas, gerando dificuldades de implantação da rede coletora de esgoto, além de reformas e ampliações de imóveis sem a devida regularização junto à Prefeitura Municipal. (SANTOS et al., 2010, p. 45)..

Porém, pode-se acrescentar, a partir do relato dos entrevistados residentes em áreas de moradias mais simples do Rio Vermelho, a solução encontrada pelos moradores que, devido à suposta morosidade no atendimento à solicitação de ligações de esgoto por parte da empresa de saneamento, optam por 'agir por conta própria'.

\section{ANÁLISE AMBIENTAL INICIAL DAS PRAIAS DO BAIRRO RIO VERMELHO}

A Bacia hidrográfica do Rio Lucaia é responsável pela drenagem de parte dos esgotos domésticos da cidade de Salvador, localiza-se ao Sul da cidade e detém uma área de $14,74 \mathrm{~km}^{2}$, ou seja, $4,77 \%$ da superfície territorial de Salvador. $\mathrm{Na}$ bacia abrigam $11 \%$ da população da cidade, o que corresponde à densidade populacional de 18.154,85 hab $/ \mathrm{km}^{2}$ (IBGE, 2000 apud SANTOS et al., 2010, p.41). Após receber efluentes diversos por todo trajeto, o Rio Lucaia deságua na Praia da Mariquita, no bairro Rio Vermelho.

Segundo Santos e outros (2010, p. 41), o rio Lucaia encontra-se totalmente antropizado, revestido e/ou encapsulado em toda a sua extensão, com águas sempre opacas e escuras. Tem o leito bastante assoreado, o que compromete o fluxo de água. Essas características são evidenciadas no pro- tocolo de avaliação rápida dos rios (PAR), cujos resultados se apresentam no Quadro 2. Segundo Rodrigues e outros (2008, p. 143), os PARs avaliam, de forma integrada, as características de um trecho do rio, conforme estado de conservação ambiental. Foram aplicados PARs em cinco estações de coleta de amostras de água na Bacia - LUC 01, LUC 02, LUC 03, LUC 04 e LUC 05 - cujas coordenadas são descritas no Quadro 3.

Quadro 2 - Observações do PAR nas estações de coleta de amostra de água da Bacia do Rio Lucaia

\begin{tabular}{|c|c|c|c|c|c|}
\hline Pardmetro & LUC 01 & LUC 02 & LUC 03 & LUC 04 & LUC 05 \\
\hline $\begin{array}{l}\text { Tipo de ocupaç̧̃o } \\
\text { das margens }\end{array}$ & Residencial & Residencial & $\begin{array}{l}\text { Comercial/ } \\
\text { administrativo }\end{array}$ & $\begin{array}{l}\text { Residencial, } \\
\text { comercial/ } \\
\text { administrativo }\end{array}$ & Residencial \\
\hline \multirow[b]{2}{*}{ Estado do leito do rio } & \multirow{2}{*}{ Assoceado } & Assoreado & \multirow[b]{2}{*}{ Revestido } & \multirow[b]{2}{*}{ Revestido } & \multirow[b]{2}{*}{ Revestido } \\
\hline & & $\begin{array}{c}\text { Revestido } \\
\text { parcialmente }\end{array}$ & & & \\
\hline Mata clliar & $\begin{array}{c}\text { Dominảncia de } \\
\text { Gramineas }\end{array}$ & Inexistente & Inexistente & Pavimentado & Pavimentado \\
\hline Plantas aquáticas & $\begin{array}{l}\text { Perifhon } \\
\text { abundante } \\
\text { e biofilmes }\end{array}$ & $\begin{array}{c}\text { Periffion } \\
\text { abundante e } \\
\text { biofilmes }\end{array}$ & $\begin{array}{c}\text { Perifiton } \\
\text { abundante e } \\
\text { biofilmes }\end{array}$ & $\begin{array}{c}\text { Perfition } \\
\text { abundante e } \\
\text { biofilmes }\end{array}$ & Ausente \\
\hline Odor da água & Forte (esgotos) & Forte (esgotos) & Fonte (espotos) & Forte (esgotos) & $\begin{array}{c}\begin{array}{c}\text { Fonte } \\
\text { (esgotos) }\end{array}\end{array}$ \\
\hline Oleosidace da água & Ausente & Moderada & $\begin{array}{l}\text { 'Marcas' em } \\
\text { linnas (arce- } \\
\text { inis) }\end{array}$ & $\begin{array}{c}\text { 'Marcas' em } \\
\text { linnas (arco-iris) }\end{array}$ & Ausente \\
\hline $\begin{array}{c}\text { Transparéncial } \\
\text { coloraçăo da àgua }\end{array}$ & $\begin{array}{l}\text { Opaca oul } \\
\text { colonida }\end{array}$ & Muito escura & $\begin{array}{l}\text { Opaca ou } \\
\text { colonda }\end{array}$ & Turva & $\begin{array}{l}\text { Opaca ou } \\
\text { colorida }\end{array}$ \\
\hline \multirow[b]{2}{*}{ Tipo de fundo } & \multirow[b]{2}{*}{ Lixo } & Lixo & $\begin{array}{l}\text { Lixo, Lama/ } \\
\text { Areia }\end{array}$ & \multirow{2}{*}{$\begin{array}{l}\text { Marcas de } \\
\text { antropizaçăo } \\
\text { (entulho) }\end{array}$} & \multirow{2}{*}{$\begin{array}{l}\text { Marcas de } \\
\text { antropizaçăo } \\
\text { (entulho) }\end{array}$} \\
\hline & & $\begin{array}{c}\text { Marcas de } \\
\text { antropizaçăo } \\
\text { (entulho) }\end{array}$ & $\begin{array}{l}\text { Marcas de } \\
\text { antropizaçăo } \\
\text { (entuino) }\end{array}$ & & \\
\hline Fluxo de águas & $\begin{array}{l}\text { Formaç̧o de } \\
\text { pequenas } \\
\text { "Illhas" }\end{array}$ & $\begin{array}{l}\text { Malor parte do } \\
\text { substrato } \\
\text { exposto }\end{array}$ & $\begin{array}{l}\text { Maior parte do } \\
\text { substrato } \\
\text { exposto }\end{array}$ & $\begin{array}{l}\text { Formaç3̄o de } \\
\text { pequenas tithas" }\end{array}$ & $\begin{array}{c}\text { Fluxo igual } \\
\text { em toda a } \\
\text { largura }\end{array}$ \\
\hline
\end{tabular}

Fonte: SANTOS e outros, 2010, p. 42

Estes pontos de coleta foram utilizados para análise da qualidade da água. Note que a estação LUC 05 localiza-se próxima à foz do rio, indicando com boa aproximação a qualidade das águas que deságuam no mar, junto à praia.

Santos e outros (2010, p. 43-45) realizaram análises em períodos chuvoso e seco, sobre parâmetros de qualidade da água, como, oxigênio dissolvido (OD), demanda bioquímica de oxigênio (DBO), Coliformes termotolerantes, Nitrogênio Total e Fósforo Total, cujos limites mínimos ou máximos são definidos na resolução do CONAMA n 357 de 17 de março de 2005 (BRASIL, 2005), que entre outras atribuições, estabelece as condições e padrões de lançamento de efluentes. Dentre as classes especificadas para águas doces nesta resolução, a classe 2, sob a qual se avalia o Rio Lucaia, é a que estabelece o padrão mais tolerável para recreação de contato primário.

No entanto, para a estação mais próxima à foz do rio (LUC 05) observou-se que todos os resultados labo- 
ratoriais referentes aos parâmetros supracitados apresentaram valores fora dos padrões estabelecidos para águas doces de classe 2. Em consequência destes resultados insatisfatórios, o Índice de Qualidade das Águas (IQA) da estação LUC 05 é péssimo no período seco e ruim no período chuvoso. As demais estações também foram qualificadas como ruim ou péssima (SANTOS et al., 2010, p. 45).

Quadro 3 - Coordenadas das estações de coleta de amostras de água da Bacia do Rio Lucaia, datum SAD69, projeção UTM e fuso 24S, Salvador, 2009.

\begin{tabular}{|c|c|c|c|}
\hline Estaçāo & Coordenada $X$ & Coordenada Y & Referência \\
\hline LUC 01 & 552772,3982 & 8564099,13 & $\begin{array}{c}\text { Av. Vale dos Barris, ao lado da } \\
\text { PMSI } \\
\text { SEUHAM. }\end{array}$ \\
\hline LUC 02 & 55474,6967 & 8563287,323 & $\begin{array}{c}\text { Av. Vasco da Gama, próximo ao } \\
\text { vaduto. }\end{array}$ \\
\hline LUC U3 & $356935,34 / y$ & $8563 / 36,0 / 6$ & $\begin{array}{c}\text { Av. Antônio Carlos Magalhães } \\
\text { (Brotas), em trente à Comercıal } \\
\text { Ramos. }\end{array}$ \\
\hline LUC 01 & 555665,0216 & 8562192,105 & $\begin{array}{l}\text { AV. Antónıo Carlos Magalhäes } \\
\text { (Rio Vermelho), em frente a } \\
\text { EMBASA. }\end{array}$ \\
\hline LUC 05 & 555495,2814 & 8561795,551 & $\begin{array}{l}\text { Av. Juracy Magalhães Junior, } \\
\text { (Rio Vermelho), em frente à } \\
\text { UNIMED. }\end{array}$ \\
\hline
\end{tabular}

Fonte: SANTOS e outros, 2010, p. 42

Dada a densidade populacional da região e a forma como o rio vem sendo utilizado, fica evidente o dano ambiental causado pelos diversos aspectos da atividade urbana. Deve-se destacar a poluição visual, o odor, a propagação de vetores de doença e o agravamento do nível de poluição em resposta a um sistema de saneamento ineficiente e à frágil consciência ambiental de parcela da população e frequentadores, evidenciada pela capacidade de poluir as ruas e praias com resíduos diversos.

\subsection{Caracterização ambiental de praias locais a partir de protocolos de campo (Checklist ${ }^{9}$ )}

Para aplicação dos protocolos de campo definiu-se um dia comercial, período vespertino de uma quinta-feira, $1^{\circ}$ de dezembro, e um domingo no período matutino, 04 de dezembro de 2011. Os dois períodos estavam ensolarados, o que permitiu identificar as praias mais frequentadas, assim como a significância do acréscimo daqueles que frequentam aos finais de semana, dias de maior demanda.

A despeito de congestionamentos em horários habituais, o acesso às praias do Rio Vermelho é facilitado pelo transporte público e fácil acesso aos pedestres. A praia do Buracão é a que exige maior caminhada para os que utilizam transporte público, mas, ainda assim não se trata de uma distância expressiva. Há áreas para o estacionamento de veículos, entretanto, com relação às condições físicas das calçadas e acesso direto às praias, há diversas limitações.

Primeiramente, não há calçadões neste trecho da orla de Salvador e tão pouco ciclovias. As estreitas calçadas, em geral, foram consideradas transitáveis, com exceção da praia da Sereia, a qual apresenta buracos, rachaduras e desníveis. Ressalta-se, portanto, que nenhuma possui acesso a cadeirantes. Com relação ao acesso direto à praia, a praia da Sereia possui quatro escadas, das quais uma em estado de deterioração, um quinto acesso consiste de trilha improvisada com estacas em declive; na praia da Paciência há duas escadas de alvenaria em boas condições, porém, o acesso é interrompido quando há escoamento dos canais de água pluvial, sendo necessário utilizar uma escada de madeira improvisada, insegura e em péssimo estado de conservação. Os acessos das demais praias não apresentaram condições inadequadas, com problemas estéticos ou de segurança.

Com exceção da praia da Mariquita, todas as praias do Rio Vermelho dispõem de cestos para coleta de resíduos, entretanto, os cestos das praias da Sereia e de Santana, além de serem pequenos com abertura estreita, estão localizados somente na calçada. Na praia da Paciência dois cestos deste mesmo tipo estão distribuídos na areia, porém, são insuficientes para o volume de resíduos gerado. Na praia do Buracão, além do simbólico cesto disponibilizado pela prefeitura são utilizados até três grandes coletores.

Foram encontrados resíduos sólidos diversos em todas as praias avaliadas, evidenciando as particularidades de cada uma delas. Os resíduos presentes na praia do Buracão resultam do uso em atividades recreativas e são originários, sobretudo, do consumo de alimentos e bebidas. Além desses resíduos, as praias da Sereia e da Paciência também apresentaram resíduos provenientes de residências, das ruas e da realização de oferendas do candomblé. Apesar de ser a mais freqüentada, a praia do Buracão registrou uma menor quantidade de resíduos sólidos.

Santana e Mariquita estão localizadas em dois núcleos da Colônia de pesca Z-1, consequentemente, entre os resíduos encontrados também se percebe a presença de vestígios de tratamento de peixe, bem como espécimes mortos à beira da praia. Em ambas as praias tam- 
bém são encontrados resíduos de utensílios utilizados em oferendas, entretanto, o destaque é dado aos resíduos característicos das ruas e de residências presentes em maior proporção na praia da Mariquita, com significativa concentração na região da foz do rio Lucaia. A presença de resíduos da construção civil é um aspecto peculiar à praia de Santana.

Com exceção da Praia da Mariquita, em que o Mercado do Peixe ${ }^{10}$ localiza-se próximo, nenhuma praia do Rio Vermelho dispõe de estrutura para atendimento dos usuários, faltam restaurantes, lanchonetes e banheiros. Verifica-se o improviso de barracas e vendedores ambulantes nas praias da Sereia, Paciência e Buracão. Nesta última, o trecho que a liga à antiga Praia da Fonte do Boi - hoje tomada pela drenagem fluvial - popularizou-se como um 'sanitário público misto'. Este tipo de comportamento não foi evidenciado nas demais praias, devendo-se ressaltar as características naturais da praia do Buracão, na qual nem sempre o banho é uma escolha racional, dada a agressividade das ondas. Apesar do risco de afogamento, não há sinalização de perigo e salva-vidas, bem como em nenhuma outra praia do bairro.

Foram encontrados alguns buracos que sinalizam a presença de siri branco (Arenaeus cribarius) (LAMARCK, 1818) nas praias da Sereia, de Santana e da Mariquita, todavia, somente na primeira um exemplar da espécie foi visualizado, em dia comercial. Trata-se de uma espécie útil como bioindicadora que vive nas praias de areias brancas, em que o raleamento aponta para o desequilíbrio ambiental (TEIXEIRA, 2012).

Processos erosivos foram evidenciados próximo à calçada na praia da Sereia e em morro na praia da Paciência. Durante as vistorias realizadas não se observou o uso de aparelhos de som ou ruídos que possam ser tratados como poluentes sonoros, apesar destas praias, com exceção do Buracão, estarem situadas em perímetro urbano de trânsito moderado.

Não há placas com informes sobre condições de balneabilidade nas praias da Mariquita e do Buracão. As placas presentes nas praias da Sereia, Paciência e Santana indicavam serem apropriadas ao banho, entretanto, traziam o símbolo do Instituto de Meio Ambiente (IMA), autarquia extinta pela lei no 12.212 de 4 de maio de 2011 que consolidou a criação do Instituto Estadual do meio Ambiente (INEMA).

Em descumprimento à lei municipal no 5.504/99 (SALVADOR, 1999) foram visualizados cães em toda a extensão das praias do bairro e somente não houve registro de pombos na praia da Sereia. Nesta mesma praia, em uma única visita, foram encontrados abelhas, calangos, camaleão e baratinhas da praia. De acordo com literatura da área as baratinhas da praia - Ligia exotica - têm na poluição sua principal ameaça e habitam entre as pedras. Exemplares de L. exotica foram encontrados nas praias de Santana, Paciência e Buracão. Moscas foram visualizadas nas praias da Mariquita e da Paciência.

Em uma escala decrescente da poluição das águas, identificada por análise sensorial, as praias do Rio Vermelho podem ser listadas como: Mariquita, Santana, Paciência, Sereia e Buracão. A praia da Mariquita ilustra intenso processo de degradação ambiental: água poluída; lodo; forte odor; algas na areia, no mar, no rio e nas pedras; e concentração de sólidos flutuantes no encontro com o rio. Além de receber a água poluída do Rio Lucaia, recebe águas de drenagem pluvial. Na praia de Santana foram encontrados lodo nas pedras e grande quantidade de algas nas pedras e pela areia, a água escura aparenta poluição, além de conter sólidos flutuantes e exalar forte odor. A água do mar da Paciência somente não possui aparência limpa na região próxima ao escoamento dos canais de drenagem, onde formavam poças de água escura esverdeada e com manchas de óleo, alimentados pelo fluído constante que advinha dos canais.

Dois canais de drenagem pluvial voltados para areia com reduzido, mas constante escoamento de efluente, são encontrados na Praia da Sereia. Há manchas escuras na areia provocadas pelo caminho feito pelos efluentes. Apesar da poluição evidente, o mar desta praia aparenta ser limpo, ressalta-se, contudo, ausência de chuva pelo menos na última semana antecedente à vistoria. Não há canais de drenagem pluvial na praia do buracão, no entanto, existem várias tubulações direcionadas à praia e no domingo foi registrado um escoamento constante oriundo de uma casa construída na praia. Ainda assim, a aparência da água é limpa.

Ressalta-se que a aplicação dos protocolos de campo foi realizada anteriormente à requalificação da orla de Salvador. Recentemente uma série de melhorias foram implementadas na orla do bairro Rio Vermelho, dentre elas, implantação de piso compartilhado entre veículos e pedestres, reorganização do trânsito, nova pavimentação, iluminação, paisagismo, implantação de galerias subterrâneas de serviços de energia e telecomunicações, entre outros fatores que contribuem para melhorar a estética 
local. No entanto, tais obras são incapazes de assegurar a balneabilidade das praias, já que não são interferências que contribuem nesse aspecto.

\subsection{Identificação de aspectos ambientais}

Dada a definição de aspecto ambiental como elemento das atividades ou produtos ou serviços de uma organização que pode interagir com o meio ambiente, fica evidente que no caso de ocorrer interação, tais aspectos podem resultar em impactos ambientais. Segundo a Resolução CONAMA 01/1986, Impacto Ambiental é:

qualquer alteração das propriedades físicas, químicas e biológicas do meio ambiente causada por qualquer forma de matéria ou energia resultante das atividades humanas que direta ou indiretamente, afetam: I - a saúde, a segurança e o bem estar da população; II - as atividades sociais e econômicas; III - a biota; IV- as condições estéticas e sanitárias do meio ambiente; e V - a qualidade dos recursos ambientais. (BRASIL, 1986).

A identificação dos aspectos ambientais favorece o levantamento dos possíveis impactos ambientais decorrentes. Seguem os aspectos ambientais associados à ação antrópica nas praias do bairro e os possíveis impactos.

\subsubsection{Geração de esgotos domésticos}

A geração de esgotos domésticos é um problema de difícil solução urbana, pois o esgoto tem origem do próprio uso da água que, por sua vez, determina as características do efluente, as quais podem variar conforme o clima, condições socioeconômicas e hábitos dos moradores. Aproximadamente $99,92 \%$ de água e $0,08 \%$ de sólidos compõem o esgoto doméstico, e esta fração componente de sólidos é suficiente para causar poluição às águas e exigir ações de tratamento (VASCONCELOS, 2008 , p. 8). A dimensão do problema do esgoto doméstico e o seu tratamento estão diretamente associados ao tamanho da população local, tendo em conta o volume médio de esgoto individual gerado, que, diante da inadequação no tratamento e destinação terá efeitos de contaminação do solo, de águas superficiais e subterrâneas e causará problemas à saúde pública.

\subsubsection{Emissário submarino}

Correntes marítimas podem realizar movimentos aleatórios que levam efluentes novamente à costa. Além disso, pode haver alteração na qualidade da água do mar em regiões próximas ao ponto de lançamento, caso não haja condições ótimas para diluição e depuração desses compostos. O emissário submarino de Salvador é construído em concreto, possui diâmetro de $1,75 \mathrm{~m}$ e comprimento de $2.350 \mathrm{~m}$, dos quais $350 \mathrm{~m}$ consistem na tubulação difusora, com diâmetro de $1,50 \mathrm{~m}$, dotada de 70 orifícios difusores com diâmetro de $15 \mathrm{~cm}$ e submersos a uma profundidade de $27 \mathrm{~m}$ (SOUZA e SILVA, 2011, p. 5). Sobre o Sistema de Disposição Oceânica do Rio Vermelho, Silva (2011, p. 4) afirma:

por se situar próxima ao Banco de Areia de Santo Antônio, e portanto em uma região com correntes hidrodinâmicas de altas magnitudes, a pluma efluente ao emissário atinge a zona de balneabilidade de Salvador com concentrações de poluente acima da permitida pela legislação ambiental vigente..

Não obstante o quadro atual de contaminação das zonas de balneabilidade de Salvador, segundo Souza e outros (2008, p. 12) "vários pesquisadores se preocupam com a sedimentação de partículas em suspensão, estranhas ao ambiente marinho, que, com o tempo, pode alterar o fundo oceânico e, com isso, as espécies bentônicas que o habitam".

\subsubsection{Lancamentos clandestinos de efluentes no Rio Lucaia}

Moradores da Vila Matos e da Vila Waldemar Falcão relataram, durante as entrevistas, terem feito instalações de esgoto por conta própria direcionando os efluentes até o Rio Lucaia. Em ambos os casos alegaram a morosidade no pedido de ligação realizado junto a Embasa como motivação para essas ligações clandestinas. $\mathrm{Na}$ Rua Alice Silveira, um morador apresentou argumento diferente, em vez de ligações clandestinas ele construiu fossa séptica, sendo o proprietário de uma das duas casas locais sem ligação ao sistema de esgoto da Embasa. Além destes relatos, o lançamento de efluentes é evidenciado pela presença de tubulações direcionadas ao rio Lucaia durante todo seu percurso dentro do bairro Rio Vermelho.

Alguns pescadores queixam-se da poluição do rio, afirmam que é comum o surgimento de micoses e que têm que recorrer ao uso de repelentes. Além das doenças de pele, outros impactos causados pelo lançamento clandestino de efluentes e consequente contaminação do rio e das praias, são o mau cheiro e a disseminação de vetores 
de doenças.

\subsubsection{Lançamentos de efluentes nas praias}

Além do rio Lucaia que deságua já sob efeitos de poluição na praia da Mariquita, de tal forma que é comumente referido como canal, há vários lançamentos de efluentes ao longo das praias do bairro Rio Vermelho, conforme evidenciam as fotografias de 1 a 6 . Foram identificados canais de drenagem pluviais nas praias da Sereia, Paciência, Santana e Mariquita.

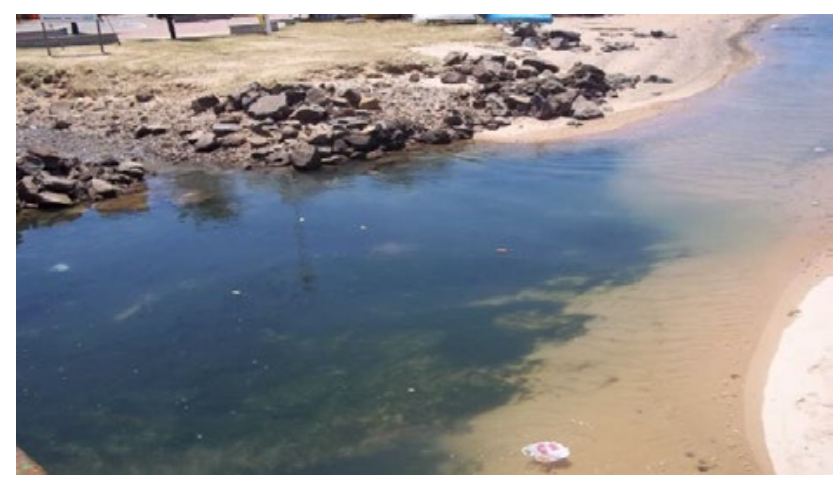

Figura 1 - Foz do Rio Lucaia, praia da Mariquita Fonte: Acervo da autora (2012)

Na praia do Buracão não foi constatada a presença de canais de drenagem pluvial, porém, há várias tubulações provenientes das residências próximas e, a praia seguinte no sentido norte-sul - a antiga praia da Fonte do Boi, ao final da rua de mesmo nome - contém uma tubulação ampla conduzindo efluentes, com grande volume mesmo durante o período seco.

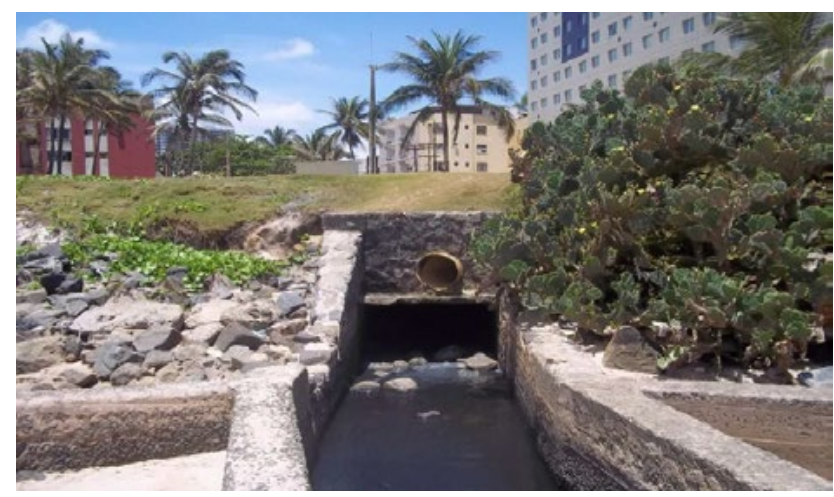

Figura 2. Canal voltado para 'Praia da Fonte do Boi' Fonte: Acervo da autora (2012)

Também se verifica lançamento de efluentes a partir do hotel Pestana, localizado na Rua Fonte do Boi entre as praias da Mariquita e do Buracão.

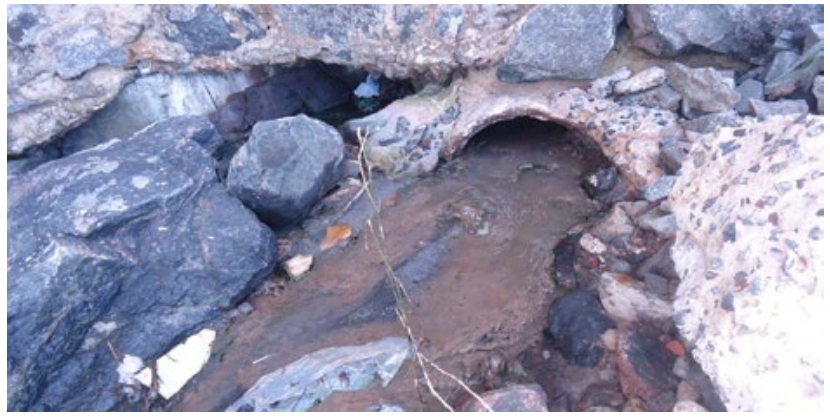

Figura 3 -Saída de efluentes ao fundo do hotel Pestana

Fonte: Acervo da autora (2012)

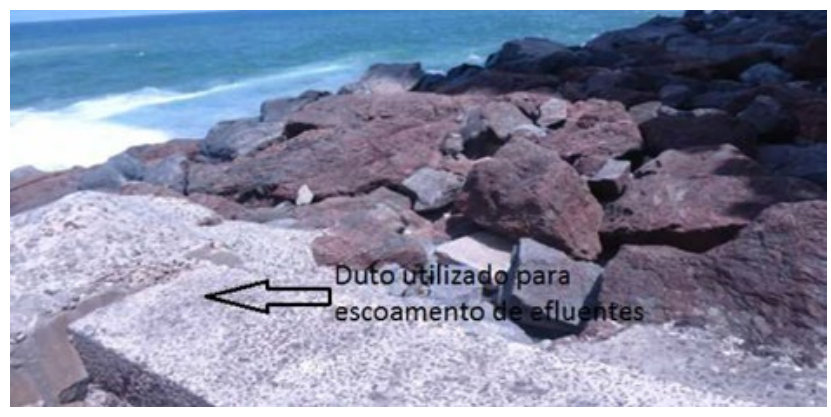

Figura 4 -Evidência de lançamento de efluentes ao mar por tubulação, ao fundo do hotel Pestana.

Fonte: Acervo da autora (2012)

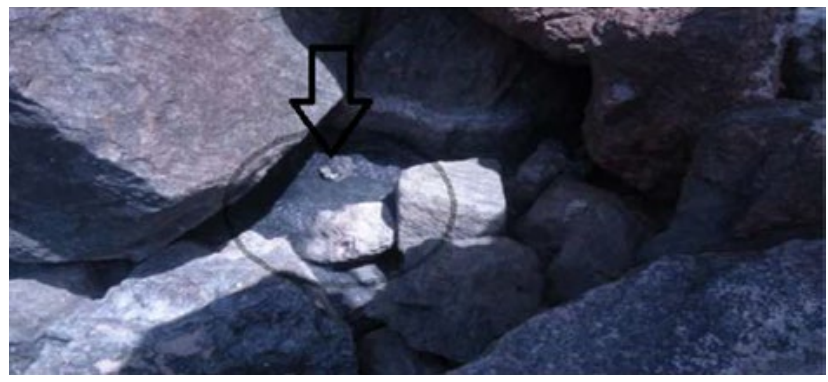

Figura 5 -Concentração de efluentes ao lado da tubulação, cujo aspecto revela ser de origem antiga: cor cinza e odor característico.

Fonte: Acervo da autora (2012)

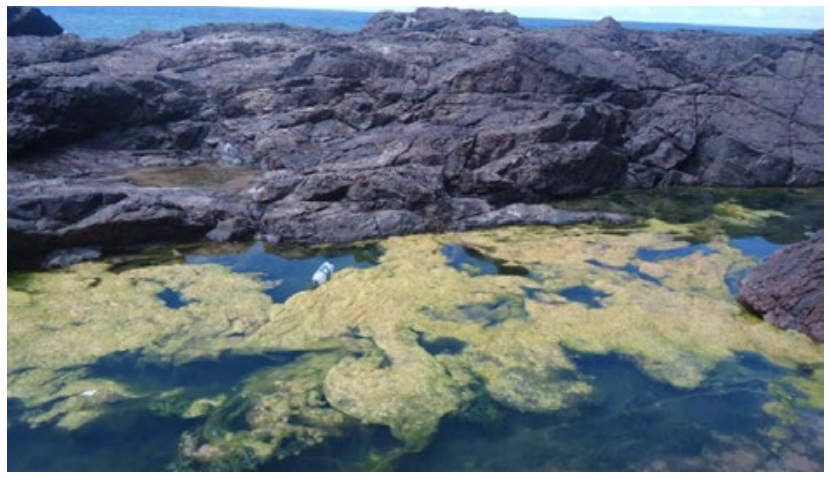

Figura 6 -Água represada ao fundo do hotel Pestana evidencia concentração de matéria orgânica.

Fonte: Acervo da autora (2012) 
Relatos de pessoas que adquiriram doenças de pele foram comuns durante a realização da entrevista. $\mathrm{O}$ caso de um pescador que contraiu estranha doença de pele foi narrado por um motorista durante a aplicação do questionário piloto e por um pescador quando da aplicação de questionários sobre valoração contingente. Neste mesmo período uma moradora da Rua Waldemar Falcão se referiu a uma amiga que adquiriu doença de pele na praia da Paciência.

\subsubsection{Descargas de efluentes pela Embasa}

Alguns moradores e pescadores relataram que a Embasa realiza descargas periódicas de efluentes no Rio Lucaia e em determinadas praias, principalmente no período chuvoso, o que foi definido por funcionária da empresa baiana de saneamento como um refluxo ocasional. A descarga de efluentes na praia de Santana (fotografia 7) foi registrada por um morador do bairro em 25 de janeiro de 2012, véspera da famosa festa de Iemanjá realizada no local. Este aspecto resulta em impactos ambientais negativos, como a contaminação da água e a disseminação de odor alterando a qualidade do ar.

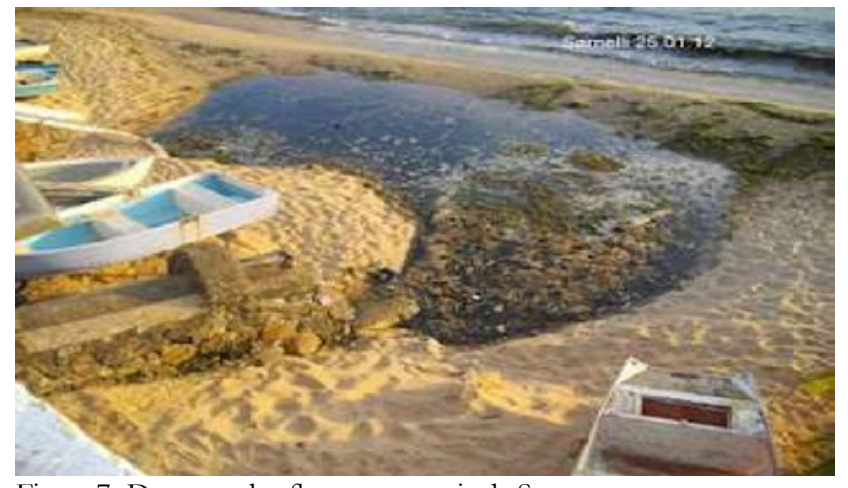

Figura 7 -Descarga de efluentes na praia de Santana.

Fonte: Blog do Rio Vemelho, por Bartolo Sarnelli, morador do bairro e colaborador do blog

Os pescadores relataram que o movimento habitual da maré leva à poluição proveniente da foz do Rio Lucaia, localizada na praia da Mariquita, até as praias próximas no sentido norte-sul, Paciência e Sereia, mas, em determinados períodos do ano o sentido da maré é inverso, logo, a praia do Buracão e o pequeno trecho que restou da Praia da Fonte do Boi passam a ser atingidos. Este fenômeno contribui para agravar os impactos relatados no item anterior.

\subsubsection{Acondicionamento inadequado de resíduos}

O arremesso de resíduos sólidos de dentro dos carros ou por pedestres nas ruas do Rio Vermelho é uma prática capaz de provocar a obstrução de bueiros e elevar a poluição do rio, por conseguinte, das praias, e o alagamento de algumas ruas na ocasião das chuvas.

Segundo pescadores, o acúmulo de lixo em frente à colônia na Praia da Mariquita é um fenômeno diário. Diversos tipos de resíduos são trazidos pelo rio, como pneus, embalagens plásticas, animais mortos e lixo hospitalar. De acordo com um dos usuários da praia, lixo hospitalar também tem sido observado noutras praias, o que aponta para uma gestão inadequada de resíduos no local.

Pescadores da praia de Santana dizem haver frequentes descartes de resíduos de construção civil nesta praia, constatação evidenciada durante a pesquisa de campo. A deposição inadequada de entulhos é um dos problemas de saneamento e limpeza urbana, em razão de seus diversos impactos, tendo em vista que os ratos, por exemplo, são os principais transmissores de leptospirose no Brasil.

\subsubsection{Produção de lixo por parte dos usuários da praia.}

Uma falha na educação ambiental é evidente entre muitos usuários das praias de Salvador,o que gera o acúmulo de resíduos e os consequentes impactos ambientais ligados a esta prática, como a criação de um ambiente propício para proliferação de vetores de doenças. Nas praias do Rio Vermelho a situação não é diferente, sendo, sobretudo, agravada pela poluição das águas. Além da poluição visual, outros impactos negativos relacionados a esse aspecto ambiental é a possível disseminação de doenças associadas a estes vetores como, por exemplo, ratos (lepstopirose); moscas (Febre Tifóide, Ancilostomose, Amebíase); pombos (suas fezes são ricas em fungos e bactérias, transmitindo diversas doenças como, por exemplo, Meningite fúngica, Criptococose, Histoplasmose e dermatites); baratas (Amebíase e Gastroenterites); e mosquitos (Elefantíase, Febre Amarela e Dengue) (VASCONCELOS, 2008).

\subsubsection{Circulação de animais domésticos: cães e gatos}

A falta de saneamento também contribui para a transmissão de doenças dos animais domésticos ou selvagens aos seres humanos. Não se constatou a presença de gatos nas praias, porém, havia uma matilha circulan- 
do principalmente entre as praias de Santana e Mariquita. Cães acompanhados, com ou sem coleira, também circulam pelas demais praias. Apesar de aparentemente inofensivos, os cães e gatos podem ser hospedeiros dos parasitas transmissores de Leptospirose, Leishmaniose e larva migrans (VASCONCELOS, 2008).

\subsubsection{Elevado indice de marginalidade e usuários de entorpecentes}

Alguns entrevistados revelaram terem deixado de frequentar as praias da Paciência e do Buracão devido à presença de usuários de entorpecentes e aos assaltos recorrentes. De acordo com alguns frequentadores, a vegetação ao lado da escada que dá acesso à praia do Buracão tem servido de abrigo a "marginais". Na praia de Santana alguns pescadores denunciaram a atuação de traficantes no local. Entretanto, no Largo da Mariquita, em poste próximo à colônia dos pescadores há uma câmera filmadora que, segundo pescador, envia imagem para delegacia e trouxe efeitos positivos ao intimidar os usuários de entorpecentes.

\subsubsection{Ausência de salva-vidas}

As praias do Rio Vermelho são pouco atrativas para o turismo, mas, ainda assim, são frequentadas. A praia da Mariquita e de Santana não atrai banhistas pela poluição evidente, já as praias da Sereia, da Paciência e, em especial a praia do Buracão são bastante frequentadas, principalmente aos fins de semana. Aparentemente a praia do Buracão é a mais limpa, entretanto, possui um mar revolto que repele mesmo os nadadores mais experientes e serve de cenário para casos esporádicos de afogamento com vítima fatal. A partir do depoimento dos entrevistados e pelas visitas às praias em diferentes períodos constatou-se a ausência de salva-vidas, o que pode favorecer, juntamente com a ausência de sinalização de perigo, a ocorrência de afogamentos.

\subsubsection{Ausência de salva-vidas}

Há trechos com erosões na encosta junto à calçada da praia da Sereia e erosões mais acentuadas no morro da praia da Paciência. Ambas implicam em impacto ambiental visual e no solo negativos; além disso, representam risco de acidente aos usuários e transeuntes.

\subsection{Requisitos legais aplicáveis}

Há leis vigentes em Salvador cuja aplicação corroboraria para a qualidade das praias e o uso social e coletivo das mesmas. Pela lei federal $\mathrm{n}^{\circ} 7.661$, de 16 de maio de 1988 não é permitida a urbanização ou qualquer forma de utilização do solo na Zona Costeira que impeça ou dificulte o acesso conforme descrito em seu $10^{\circ}$ artigo:

Art. 10. As praias são bens públicos de uso comum do povo, sendo assegurado, sempre, livre e franco acesso a elas e ao mar, em qualquer direção e sentido, ressalvados os trechos considerados de interesse de segurança nacional ou incluídos em áreas protegidas por legislação específica.

$\int 1^{\circ}$. Não será permitida a urbanização ou qualquer forma de utilização do solo na Zona Costeira que impeça ou dificulte o acesso assegurado no caput deste artigo. (BRASIL, 1988).

As barracas da orla de Salvador tiveram sua demolição determinada por decisão judicial em processo instaurado no ano de $2006^{11}$. Após decisão judicial, foi iniciado o processo de retirada das 352 barracas no dia 23 de agosto de 2010 (VERA, 2013, p.310), fundamentada pela referida lei e impulsionada pelas irregularidades identificadas pela vigilância sanitária. Desde então predominam vendedores ambulantes sob práticas de preços elevados pelo aluguel de cadeiras e guarda-sóis, o que tem causado frequente insatisfação dos usuários das praias. Os entrevistados frequentemente apontam os vendedores e, em especial, os proprietários das barracas extintas, como os principais colaboradores para limpeza das praias. Entretanto, há registro de outras instalações fixas à beira das praias, infraestruturas hoteleiras têm acesso privilegiado ao mar e às praias. A fotografia 8 retrata como a praia do Buracão é tomada por construções.

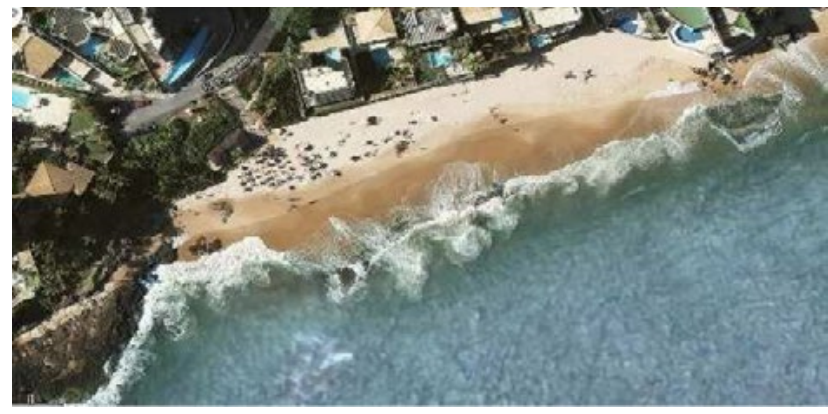

Figura 8. Construções se apropriaram da praia do Buracão Fonte: Google Maps, 2012

A Lei $n^{\circ}$ 5.504/99 institui o código municipal de saúde de Salvador (SALVADOR,1999) e proíbe por meio do artigo 187 o trânsito de cães nas praias. No entanto, além das matilhas habituais que circulam principalmente nas praias de Santana e Mariquita, frequentemente cães 
circulam nas praias do Rio Vermelho acompanhados dos donos, que, geralmente não dispõem de sacos para coleta de dejetos.

As resoluções do CONAMA têm força de lei, entretanto, isto não tem sido suficiente para uma adequada gestão do rio Lucaia, cuja foz deságua na praia da Mariquita, mas fora dos padrões estabelecidos pela Resolução CONAMA n. ${ }^{\circ}$ 357/05 (BRASIL, 2005) para águas doces classe 2, tanto no período chuvoso quanto no período seco conforme assinalam Santos et al. (2010, p. 44).

Ainda em descumprimento a resolução do CONAMA, segundo Souza e Silva (2011, p. 6-7), a pluma de efluente do emissário atinge a costa da cidade de Salvador com concentrações acima do que estabelece a resolução $\mathrm{n}^{\circ} 274$, que institui os padrões de balneabilidade (BRASIL, 2000).

Segundo o Plano municipal de saneamento básico de Salvador, que expõe o diagnóstico da situação dos serviços de limpeza urbana e manejo de resíduos sólidos, a limpeza de praias consiste na retirada de resíduos em toda a sua extensão, limpeza e catação das áreas verdes, esvaziamento de lixeiras e manutenção de faixas litorâneas de praias localizadas desde o Subúrbio Ferroviário até a Praia do Flamengo, incluindo, portanto, praias do Rio Vermelho (BAHIA, 2010, p. 107). O plano também prevê, limpeza manual, com distribuição de equipes de agentes de limpeza conforme demanda, onde promovem a limpeza durante todo o turno de trabalho; e limpeza mecanizada, com a retirada de resíduos com o auxílio de máquina e equipamentos específicos (BAHIA, 2010, p. 109).

\subsection{Práticas e procedimentos ambientais existentes}

O monitoramento da balneabilidade das praias de Salvador é realizado semanalmente pelo INEMA. Porém, essa operação não abrange todas as praias do Rio Vermelho, já que o monitoramento no bairro é restrito a dois pontos de coleta, nas praias Paciência e Santana. As conclusões dos boletins de balneabilidade para os meses de novembro e dezembro de 2011 são apresentados no Quadro 4.

A partir dos boletins de monitoramento referentes ao período de realização do trabalho de campo (novembro e dezembro de 2011), verificou-se que, a balneabilidade das praias, conforme a classificação estabelecida na resolução $n^{\circ} 274$ do CONAMA, oscila entre própria ou imprópria, a depender do período. Segundo os moradores, a coleta de resíduos sólidos no bairro por parte da Limpurb - Empresa de Limpeza Urbana do Salvador - ocorre às terças e quintas-feiras. Essa operação é observada com maior frequência nas praias, mas pôde-se registrar também, durante estes dois meses - período de realização das entrevistas e aplicação dos protocolos de campo - frequente presença de funcionários da Limpurb na praia de Santana em atividades recreativas com os pescadores.

Quadro 4 - Boletins de balneabilidade das praias do Rio Vermelho Novembro-Dezembro 2011

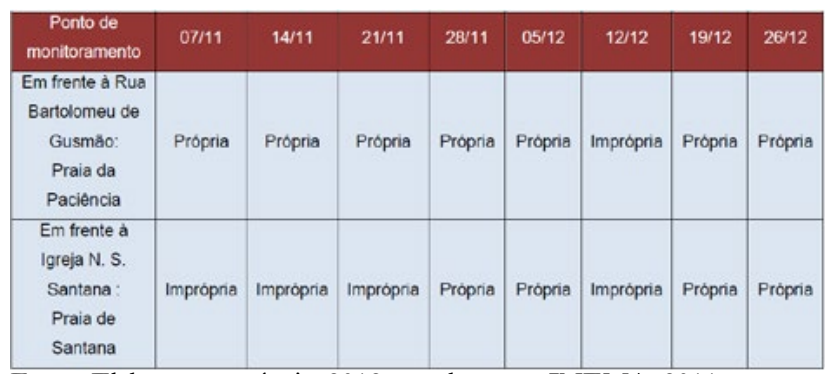

Fonte: Elaboração própria, 2012 com base em INEMA, 2011

Em geral, durante as entrevistas, os pescadores se empenharam em demonstrar uma boa consciência ambiental. O representante da colônia dos pescadores da praia da Mariquita descreveu um projeto de sua autoria para despoluição do rio através do gradeamento ${ }^{12}$ e vários pescadores afirmaram ter o hábito de promover a limpeza por meio da catação dos resíduos. Alguns pescadores declararam a adoção de práticas de não jogar sujeiras ao mar durante a pescaria, outros chegaram a afirmar que utilizam âncoras de tecnologia indígena para não gerar danos ambientais.

\subsection{Situações emergenciais e acidentes anteriores}

Todas essas não-conformidades descritas quando do levantamento de aspectos e impactos ambientais, representam situações emergenciais. Entretanto, algumas recebem destaque devido à existência de acidentes anteriores. São as doenças de pele e os afogamentos descritos por alguns entrevistados. Afogamentos ocorrem em especial na praia do Buracão, por causa de mar agitado, correntes marítimas, declividade, e, assim como as outras praias, pela ausência de sinalização de risco e salva-vidas.

\section{CONSIDERAÇÕES FINAIS}


Tendo em vista que a história do bairro Rio Vermelho antecede à da cidade de Salvador, o estudo de suas praias, além de considerar a beleza natural e alterações ambientais, faz jus a atributos históricos e culturais significativos. Contudo, a atualidade revela as consequências de um crescimento urbano desordenado e de uma gestão ineficiente dos recursos naturais.

Durante a fase de entrevistas, foram verificadas frequentes denúncias sobre os mesmos aspectos ambientais, sinalizando a veracidade das mesmas, destacando-se o fato de moradores e pescadores afirmarem terem identificado a presença de lixo hospitalar nas praias, como também, alguns dos entrevistados relatarem casos de doenças de pele adquiridas nas praias e, principalmente, por vários moradores denunciarem os mesmos lançamentos clandestinos de efluentes. Tais fatos guiaram a pesquisa em seu caráter investigativo. Dessa forma, a população contribuiu para o conhecimento de situações de tal modo que, sem esta colaboração, esta pesquisa estaria incompleta, ou, no mínimo, a descoberta dos aspectos ambientais denunciados seria incerta.

A Análise Ambiental Inicial realizada consoante à NBR ISO 14004 possibilitou importantes constatações. Além de as praias do Rio Vermelho serem poluídas com resíduos de origens diversas, carecem de atenção quanto ao acesso, pois há improvisos e alguns trechos em que as calçadas são intransitáveis, e revitalização de encostas. Estas praias também demandam uma gestão eficiente dos resíduos, de modo a evitar, entre outras irregularidades, o transbordamento de cestos coletores e a deposição de entulhos. A necessidade de limpeza das praias foi apresentada espontaneamente por $53,68 \%$ dos moradores e $54,84 \%$ dos pescadores entrevistados, quando perguntados sobre o que deveria melhorar nas praias do bairro Rio Vermelho.

Para transformar a atualidade das praias do bairro Rio Vermelho, tornando-as limpas, evidentemente, é necessário investimento financeiro adequadamente direcionado. Contudo, algumas ações eficientes para obtenção de praias limpas no bairro dependem mais do cumprimento da legislação existente ou de um comportamento ambientalmente saudável do que da disponibilização de recursos financeiros.

\section{REFERÊNCIAS BIBLIOGRÁFICAS}

ASSOCIAÇÃO BRASILEIRA DE NORMAS TÉCNI-
CAS. NBR ISO 14004: Sistemas de gestão ambiental - diretrizes gerais sobre princípios, sistemas e técnicas de apoio. Rio de Janeiro, 2007, $53 \mathrm{f}$.

BRASIL. Resolução CONAMA n ${ }^{\circ}$ 001/1986, de 23 de janeiro de 1986. Dispõe sobre critérios básicos e diretrizes gerais para o Relatório de Impacto Ambiental - RIMA. Diário Oficial [da] República Federativa do Brasil, p. 2548-2549,17 fev. 1986.

BRASIL. Resolução CONAMA No 274/2000, de 29 de novembro de 2000. Revisa os critérios de Balneabilidade em Águas Brasileiras. Diário Oficial [da] República Federativa do Brasil , n 018, p. 70-71, 08 jan. 2001.

BRASIL. Resolução CONAMA No 357/2005, de 17 de março de 2005 Dispõe sobre a classificação dos corpos de água e diretrizes ambientais para o seu enquadramento, bem como estabelece as condições e padrões de lançamento de efluentes, e dá outras providências. Diário Oficial [da] República Federativa do Brasil. no 053, p. 58-63, 18 mar.2005.

FAGGIONATO, S. Percepção ambiental. Disponível em: <www.educar.sc.usp.br/textos> Acesso em: 25 maio 2012

IBGE - Instituto Brasileiro de Geografia e Estatística. CENSO Demográfico de 2010: Dados populacionais do bairro Rio Vermelho. Fornecida pela Unidade Estadual do IBGE na Bahia. Salvador: IBGE; 2010.

MARTINS, Cintia Dalcuche Leal. Avaliação do impacto da urbanização sobre a heterogeneidade química e a estrutura das comunidades fitobênticas: uma abordagem integrada. Dissertação (Programa de pós-graduação em Ecologia) Universidade Federal de Santa Catarina, Florianópolis, 2011.

MATA, Henrique Tomé da Costa. Impactos da poluição industrial na economia brasileira. Tese (Doutorado em Economia Aplicada) - Universidade Federal de Viçosa, Minas Gerais, 2001

PORTO FILHO, Ubaldo Marques. Histórico do bairro Rio Vermelho e da transformação de suas praias. Salvador, residência do entrevistado, 03 dez. 2011. Entrevista à autora. 
PORTO FILHO, Ubaldo Marques. Rio Vermelho. Salvador, 1991.

PORTO FILHO, Ubaldo Marques. Rio Vermelho, de Caramuru a Jorge Amado. Salvador, 2009.

Porto Filho, ACIRV. Revista do Rio Vermelho. Disponível em: $<$ http://www.acirv.org/hp/revista. asp?id=4\&tipo=geral Acesso em: 04 jan. 2011.

RODRIGUES, A. S. L. ; MALAFAIA, G. ; CASTRO, P. T. A. Protocolos de avaliação rápida de rios e a inserção da sociedade no monitoramento dos recursos hídricos. Revista Ambiente \& Água, Taubaté, v. 3, n. 3, p. 143-155, 2008.

SALVADOR. LEI $\mathbf{N}^{\circ}$ 5.504/99 Institui o CÓDIGO MUNICIPAL DE SAÚDE. Publicado no Diário Oficial do Município de Salvador (DOM) - 01 de março de 1999

SALVADOR. Secretaria Municipal dos Transportes Urbanos e Infraestrutura. Plano municipal de saneamento básico: $1^{\circ}$ Etapa - Diagnóstico da situação do saneamento básico em Salvador, serviços de limpeza urbana e manejo de resíduos sólidos. Salvador, set. 2010.

SANTOS, E. et al. (Orgs.). O caminho das águas em Salvador: bacias hidrográficas, bairros e fontes. Salvador: CIAGS/UFBA; SEMA, 2010.

SOUZA E SILVA, Mario Grune. Otimização do emissário do Rio Vermelho, Salvador - BA, via Modelagem Computacional. 2011. 84 f. Trabalho de conclusão de curso (Graduação em Engenharia Ambiental). - Escola Poltécnica, UFRJ, Rio de Janeiro, 2011.

SOUZA, José. F. A. S.; AZEVEDO, José L. L. A. ; OLIVEIRA, L. R. ; SOARES, Ivan D. Emissários submarinos - uma alternativa para a disposição final de efluentes em cidades costeiras. In: SEMINÁRIO E WORKSHOP EM ENGENHARIA OCEÂNICA, 3., 2008, Rio Grande. Anais... Rio Grande: FURG, 2008, p.1-12.

TEIXEIRA, Ricardo Marandino. Crustáceos. Disponível em: <http://www.vivaterra.org.br/crustaceos. htm\#baratinhapraia>. Acesso em: 05 jan. 2011.

VASCONCELOS, Sandra Maria Santos de. Tratamento de efluentes domésticos. Goiânia: CEFET, 2008. Textos elaborados para disciplina Tratamento de Efluentes Do- mésticos do curso superior de Tecnologia em Saneamento Ambiental.

VERA, L. A. R; LADEIRA, R; COSTA, A.S. A retirada das barracas de praia da orla de Salvador na perspectiva de turistas e moradores. Caderno Virtual de Turismo. Rio de Janeiro, v. 13, n. 3., p.308-323, dez 2013

\section{Notas de Fim:}

1- Conforme lista com pontos de coleta apresentados no endereço eletrônico do INEMA, nos anos de 2011 e 2012, no bairro Rio Vermelho eram monitoradas somente as praias da Paciência e de Santana. Atualmente a praia do Buracão também é monitorada.

2- Elementos das atividades, produtos e serviços da organização que possam interagir com o meio ambiente.

3- Percepção ambiental refere-se ao modo como o indivíduo percebe o ambiente, suas expectativas, satisfações, insatisfações, julgamentos e condutas. Cada indivíduo percebe, reage e responde diferentemente frente às ações sobre o meio (FAGGIONATO, 2012).

4- Evolução do nome tupi comoroipe, camoro (vermelho) ipê (rio).

5- O Caminho das Águas em Salvador - bacias hidrográficas, bairros e fontes. Disponível em: <http://www.pnud.org.br/publicacoes/ atlas_salvador/index.php $>$. Aqui referenciado como (SANTOS et al., 2010).

6- O nome Mariquita é uma corruptela de "mairaquiquiig", um vocábulo tupi que quer dizer "lugar que dá peixe miúdo". No passado, em certas épocas do ano, a praia da Mariquita ficava repleta de uma espécie pequena, chamada petitinga. (PORTO FILHO, 1991, p.2, cap. 15).

7- Empresa Baiana de Águas e Saneamento S.A.

8- Organismos que vivem aderidos a vegetais ou a outros substratos suspensos.

9- Protocolos de campo apropriados para organizar informações relevantes de forma pragmática a partir do preenchimento de questões e lacunas relacionadas ao objeto de estudo por meio de uma listagem previamente definida.

10- Atrativo turístico do bairro, composto por bares e restaurantes e atendido por sanitários.

11- Processo de $\mathrm{n}^{\circ}$ 16416-62.2006.4.01.3300 de autoria do Ministério Público Federal, tendo como réus: Superintendencia do Meio Ambiente, município de Salvador , Instituto Brasileiro do Meio Ambiente e dos Recursos Naturais Renovaveis (IBAMA). O referido processo pode ser consultado em: www.trf1.jus.br . 
12- Primeira etapa de uma estação de tratamento, tanto de água para abastecimentos quanto para águas residuárias.

\section{Correspondência da autora:}

Kallenya Thays Lima Limeira Oliveira

e-mail: kallenya.thays@gmail.com

Artigo recebido em: 13/11/2015

Revisado pela autora em: 09/11/2016

Aceito para publicação em: 05/12/2016

Geografia, Ensino \& Pesquisa, Vol. 21 (2017), n.1, p. 190-205

ISSN: 2236-4994 DOI: 10.5902/2236499420452 